Technical Note

\title{
A Simple and Fast Manual Centrifuge to Spin Solutions in 96-Well PCR Plates
}

\author{
Ken Motohashi ${ }^{1,2}$ (D) \\ 1 Department of Frontier Life Sciences, Faculty of Life Sciences, Kyoto Sangyo University, Kamigamo \\ Motoyama, Kita-ku, Kyoto 603-8047, Japan; motohas@cc.kyoto-su.ac.jp; Fax: +81-75-705-1914 \\ 2 Center for Plant Sciences, Kyoto Sangyo University, Kamigamo Motoyama, Kita-Ku, Kyoto 603-8047, Japan \\ Received: 15 May 2020; Accepted: 24 May 2020; Published: 25 May 2020

\begin{abstract}
A simple and fast manual centrifuge was developed to spin down solutions in 96-well polymerase chain reaction (PCR) plates. A commercially available salad spinner was utilized for this purpose. Acceleration and deceleration of the centrifuge were faster than those of a conventional electric centrifuge using 96-well PCR plates. Solutions in a 96-well PCR plate settled quickly after centrifuging for only $3 \mathrm{~s}$. This lightweight centrifuge can be stored under a laboratory bench or on a shelf and can be put on the bench only when required, whereas the electric centrifuge is immobile due to its weight and the requirement of electric cables. This simple centrifuge is inexpensive, requires minimal effort for making, and can be used anywhere.
\end{abstract}

Keywords: centrifuge; 0.2-mL 96-well PCR plate; high-throughput screening; PCR solution; spin-down

\section{Introduction}

Genotyping by polymerase chain reaction (PCR) is an important technique for screening mutants in various organisms [1-3] and genome editing by CRISPR/Cas9 [4-7]. Mutant screening by PCR is efficient for multiple samples. Escherichia coli colony-PCR is also an efficient technique for screening positive colonies [8-10], especially for high-throughput-cloned E. coli plasmids expressing recombinant proteins [11]. Microfluidic devices have recently been coupled with PCR as a method for high-throughput PCR screening [12]. However, conventional PCR using plasticware (0.2-mL 96-well PCR plates) are also widely used in high-throughput PCR screening. Since screening reactions include small volumes of PCR mixtures $(\sim 10 \mu \mathrm{L})$, the solution is required to be spun down before agarose gel electrophoresis [13-15]. Several commercially available electric centrifuges can be used for this purpose. However, these centrifuges require a few seconds for acceleration and deceleration to spin the PCR solutions down in 96-well PCR plates. Moreover, the machines require electricity and occupy significant amounts of space on laboratory benches.

A commercially available salad spinner can be used as a low-cost alternative to cytocentrifuges $[16,17]$. The basket in the salad spinner can rotate at $\sim 600$ revolutions per minute (rpm) [16]; this speed of rotation and centrifugal force is sufficient for hematocyte preparations [16,17]. Recently, a high-speed hand-powered paper centrifuge was developed for separation of plasma from whole blood [18]. The paper centrifuge can simultaneously process eight samples with high centrifugal forces of $30,000 \times$ g. In this study, I developed a manual centrifuge to spin solutions down in 96-well PCR plates for conventional PCR screening, thereby significantly improving the commercially available salad spinner. The manual centrifuge is lightweight, portable, and usable in any space. 


\section{Experimental Design}

A manual centrifuge was developed to spin solutions in 96-well PCR plates with a base to fix two 96-well PCR plates that can be centrifuged simultaneously. The improved salad spinner can be used as a simple centrifuge machine with a speed of $~ 700 \mathrm{rpm}$ and functions efficiently with 96-well PCR plates for a short spin. A conventional electric centrifuge was used to compare the characteristics of the manual centrifuge.

\subsection{Materials}

Polystyrene foam $(200 \times 200 \mathrm{~mm}$, thickness $25 \mathrm{~mm})$ was procured from the lid of a reagent delivery box and used as the base for fixing two 96-well PCR plates. A salad spinner (Pearl Metal Co., Ltd., Sanjo, Japan; Cat. No.; Petit chef Jr C-750, http://www.kitchen-tool.com/goods_C-750.html, https://amzn.to/2AkQcN0) was used as the body of the manual centrifuge to spin solutions down in 96-well PCR plates. A semi-skirted 0.2-mL 96-well PCR plate (Nippon Genetics, Tokyo, Japan; Cat. no.; 4Ti-0760) was used to spin solutions down with the manual and electric centrifuges. EZ-Vision One DNA 6× loading buffer (VWR Life Science, Radnor, PA, USA; Cat. No.; N472-KIT) was used to stain DNA after agarose gel electrophoresis [19].

2.2. Making the Manual Centrifuge for Spinning down Solutions in 96-Well PCR Plates (Time for Completion: $\sim 30 \mathrm{~min}$ )

\subsubsection{Processing Polystyrene Foam for the Base to Fix Two 96-Well PCR Plates}

A circle of diameter $150 \mathrm{~mm}$ was cut out of the polystyrene foam (Figure 1A left) and the upper surface of the foam was scraped (hatched area) to a depth of $10 \mathrm{~mm}$ using a cutter knife (Figure $1 \mathrm{~A}$ (right) and Figure 2B) to fix two 96-well PCR plates. The base of the processed polystyrene foam was placed at the bottom of the salad spinner (Figures 1B and 2A).

A

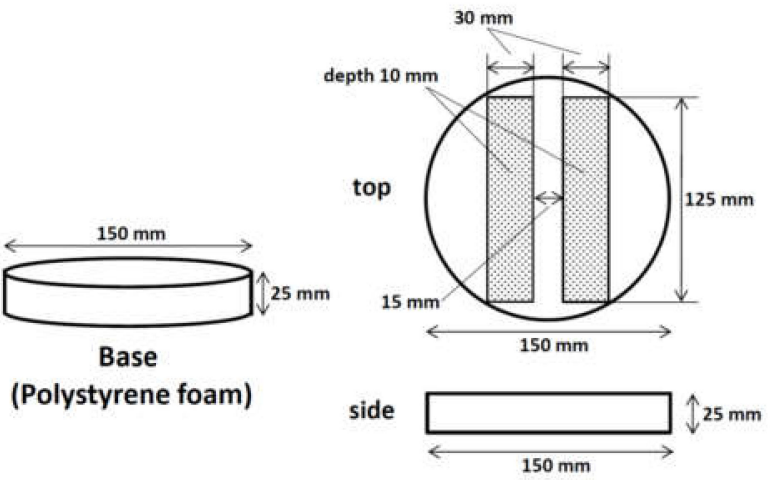

B
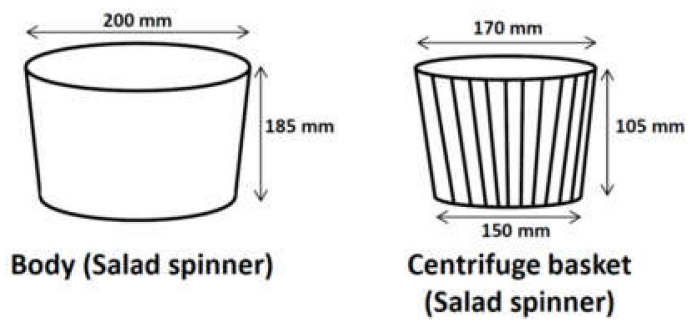

Figure 1. Design of the manual centrifuge for 96-well PCR plates. (A) The base to fix two 96-well PCR plates during centrifugation. Polystyrene foam was cut into a 150-mm diameter circle (left). The upper surface of polystyrene foam (hatched area) was scraped out at $10 \mathrm{~mm}$ depth (right) as a base to fix the two 96-well PCR plates. (B) Body (left) and centrifuge basket (right) of salad spinner. 
A
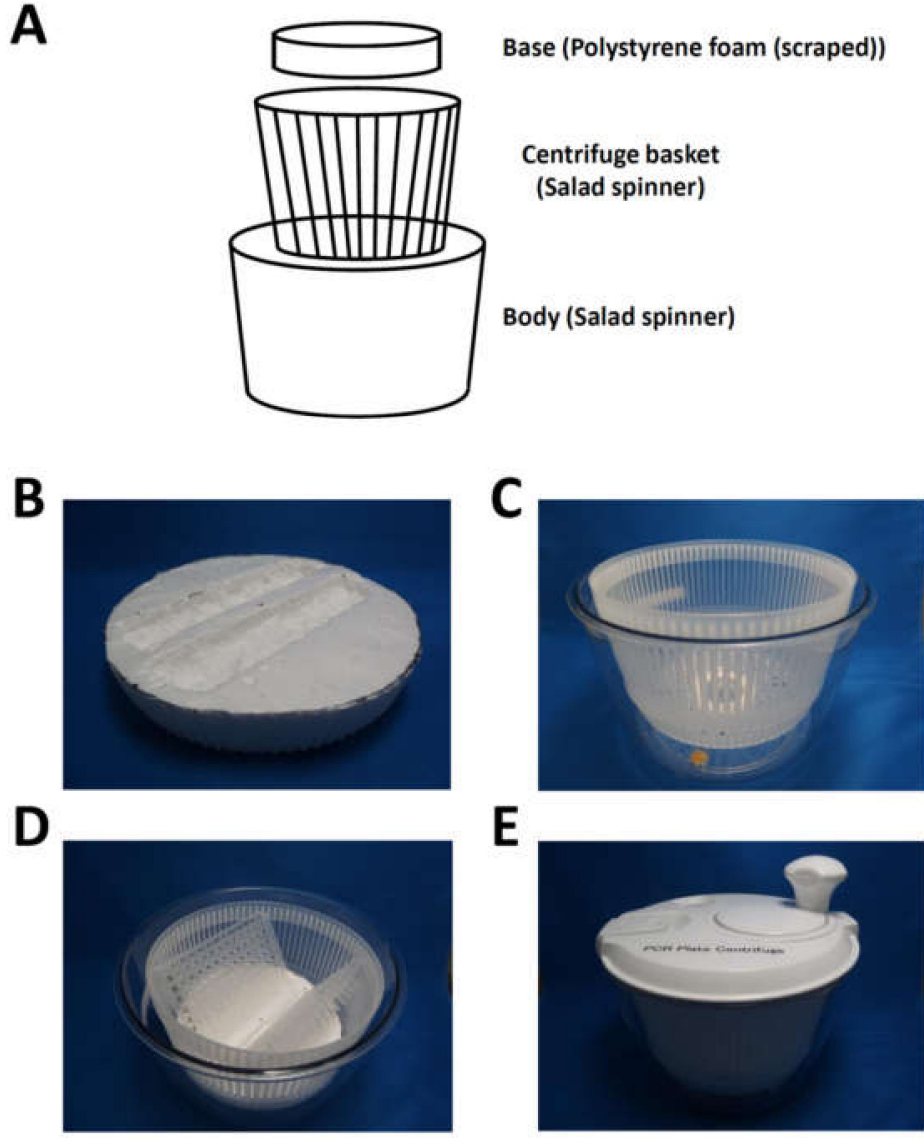

$\mathbf{E}$

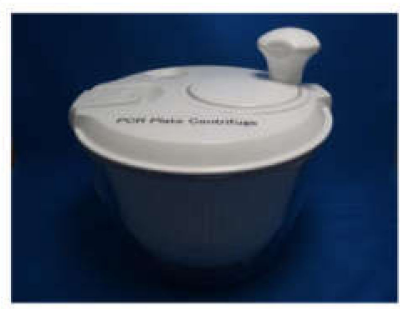

Figure 2. Assembly of the manual centrifuge for two 96-well PCR plates. (A) Processed polystyrene foam base as placed into the bottom of the salad spinner. (B-E) Manual centrifuge for 96-well PCR plates. A base made of polystyrene foam (B) and parts of the salad spinner (C) were assembled to fix and centrifuge two 96-well PCR plates (D). The complete assembled manual centrifuge (E).

\subsubsection{Assembly of the Manual Centrifuge}

The processed polystyrene foam base was assembled with the body and centrifuge basket (Figure 2A). Figure 2B-E show the parts and assembled centrifuge used to spin solutions down in the 96-well PCR plates.

\subsection{Equipment}

The MPS 1000 Mini Plate Spinner Centrifuge (Labnet International, Inc., Cary, NC, USA; https://www.labnetinternational.com/products/laboratory-centrifuges/mini-centrifuges/mps1000-mini-pcr-plate-spinner) was used as the control electric centrifuge to spin solutions down in 96-well PCR plates in comparison with the manual centrifuge developed in this study.

\section{Procedure}

Centrifuging Solutions in 96-Well PCR Plates before DNA Agarose Gel Electrophoresis (Time for Completion: $\sim 5 \mathrm{~min})$

1. Add $2 \mu \mathrm{L}$ of EZ-Vision One to all PCR samples $(10 \mu \mathrm{L})$ in 96-well PCR plates.

2. Set two 96-well PCR plates on the base of the manual centrifuge (Figure 2D).

A CRITICAL STEP: When centrifuging one 96-well PCR plate, another should be placed on the opposite side for balance.

3. Rotate the handle of the salad spinner for $3 \mathrm{~s}$. 
4. Check that the PCR mixtures have settled to the bottom of the wells in the 96-well PCR plate and load samples for agarose gel electrophoresis [19]. OPTIONAL STEP: The centrifuge can also be used to spin the PCR reaction mixtures down in 96-well PCR plates before PCR.

\section{Expected Results}

PCR solutions in 96-well PCR plates were sufficiently centrifuged using the manual centrifuge for $3 \mathrm{~s}$ (Figure 3A). DNA fragments from these centrifuged PCR mixtures could be clearly visualized by DNA agarose gel electrophoresis (Figure 4) [19].

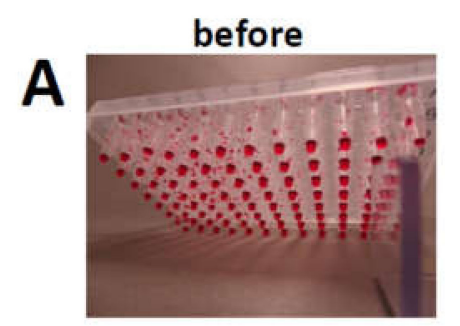

before

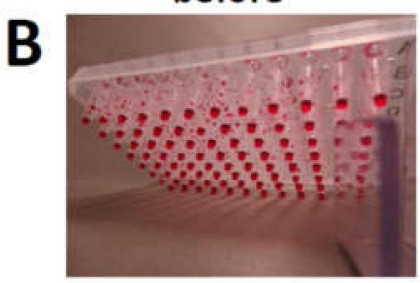

before

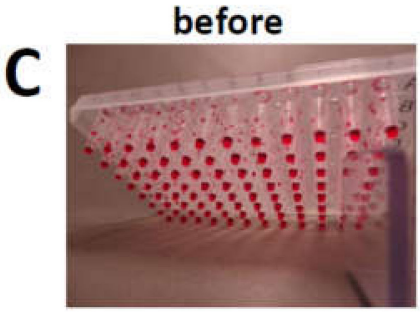

before

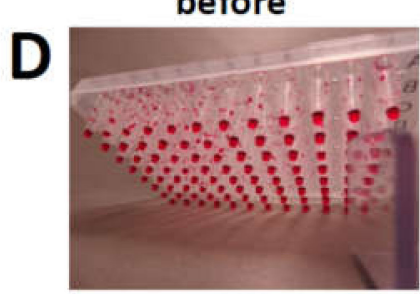

3 sec.

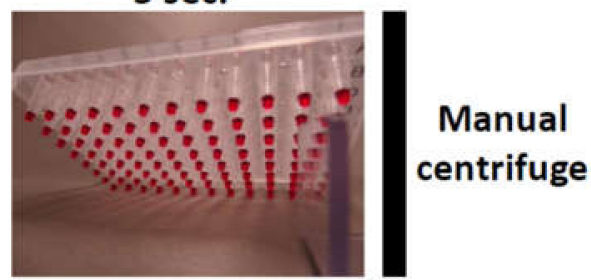

3 sec.

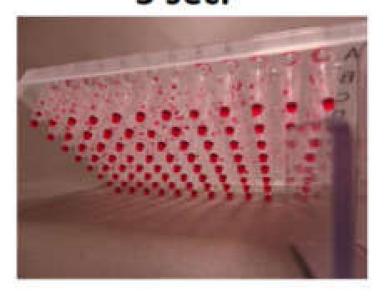

$10 \mathrm{sec}$.

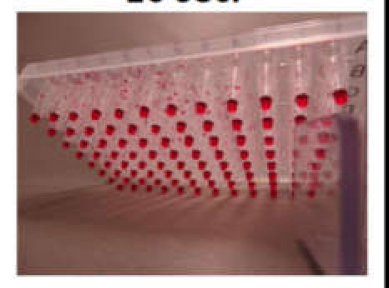

20 sec.

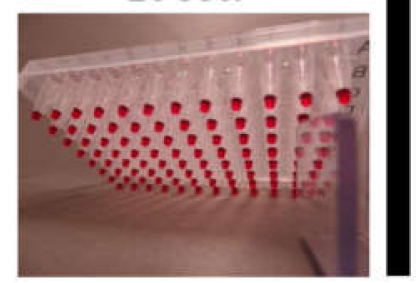

Electric centrifuge

Figure 3. Centrifuged PCR solutions in 96-well PCR plates. The efficiency of centrifuging the PCR solutions was evaluated before (left) and after (right) spinning. Centrifugation was performed for the indicated times (right; the times include start and stop of rotation). Manual centrifuge (A). Electric centrifuge (B-D). 

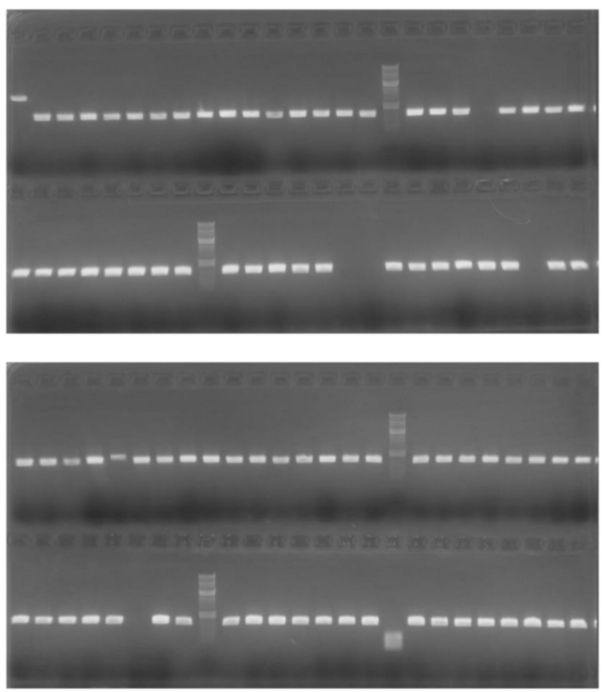

Figure 4. Analysis of spun-down PCR samples by DNA agarose gel electrophoresis. The colony-PCR samples for positive clone screening were stained with EZ-Vision One DNA 6× loading buffer, separated by $1.2 \%$ agarose gel electrophoresis [20], and visualized by a combination of a black light and a longpass emission-filter (SC-46, Fujifilm, Tokyo, Japan) [19].

In contrast, using the conventional electric centrifuge resulted in poor centrifugation after 3 and $10 \mathrm{~s}$ (Figure 3B,C); this could be attributed to the long time required for acceleration and deceleration. Centrifugation for $20 \mathrm{~s}$ by the electric centrifuge was necessary to sufficiently spin the 96-well PCR plates (Figure 3D). In contrast to the manual centrifuge, the electric centrifuge has a heavy metal drive system for centrifugal forces higher than $500 \times g$, which is associated with a longer duration of acceleration and deceleration during centrifugation. The manual centrifuge developed in this study is a light plasticware that can accelerate and decelerate quickly to help the mixtures with settling down. Therefore, although the manual centrifuge did not rotate at a high speed or centrifugal force, $3 \mathrm{~s}$ was enough to spin the solutions down in the 96-well PCR plates. The manual centrifuge using a commercially available salad spinner was previously developed with a relative centrifugal force of $24 \times g$ for centrifugation of blood samples (Table 1) [16,17]. The manual centrifuge developed in this study was modified to centrifuge solutions in 96-well PCR plates and its centrifuge force $(25 \times g)$ was similar to that previously reported [16]. Although the manual centrifuge developed in this study has to be constructed by the user, its construction is simple and takes a short time ( 30 min). The polystyrene foam base was simply cut out and set into the bottom of the salad spinner to fit two 96-well PCR plates.

Table 1. Features of hand-powered manual centrifuges for various applications.

\begin{tabular}{|c|c|c|c|}
\hline & $\begin{array}{l}\text { Manual Centrifuge for } \\
\text { the 96-Well PCR Plates }\end{array}$ & $\begin{array}{l}\text { Manual Centrifuge for } \\
\text { the Blood Sample }\end{array}$ & $\begin{array}{l}\text { Paper Centrifuge for } \\
\text { the Blood Sample }\end{array}$ \\
\hline Application & $\begin{array}{c}\text { Spin-down for PCR } \\
\text { solution }\end{array}$ & $\begin{array}{l}\text { Separation of plasma for } \\
\text { whole blood }\end{array}$ & $\begin{array}{c}\text { Separation of plasma for } \\
\text { whole blood }\end{array}$ \\
\hline Sample Capacity & 96 samples $\times 2$ & 30 samples & 8 samples \\
\hline Materials & Salad spinner & Salad spinner & Paper and string \\
\hline Maximum Speed & $760 \mathrm{rpm}(25 \times \mathrm{g})$ & $600 \mathrm{rpm}(24 \times \mathrm{g})$ & $125,000 \mathrm{rpm}(30,000 \times \mathrm{g})$ \\
\hline Price & USD 18 & USD 35 & USD 0.2 \\
\hline Weight & $0.59 \mathrm{~kg}$ & $1.5 \mathrm{~kg}$ & $2 \mathrm{~g}$ \\
\hline Reference & This study & [16] & [18] \\
\hline
\end{tabular}

Table 2 shows the features of the two centrifuges for the 96-well PCR plates. The conventional electric centrifuge for 96-well PCR plates had insufficient acceleration and deceleration and required a few tens of seconds to spin the solutions down in the 96-well PCR plates. Moreover, the electric 
centrifuge had a built-in electric motor, which made it heavy owing to the presence of multiple components. Therefore, the machine was hard to move and constantly occupied a significant amount of space on the laboratory bench. In contrast, the manual machine developed in this study was light $(\sim 0.59 \mathrm{~kg})$ and could be carried with one hand. When not needed, the machine could be stowed under a laboratory bench or on a shelf. Recent research utilizes a wide range of techniques from molecular biology to biochemistry. Thus, the efficient use of small laboratory space for successfully performing a variety of experiments requires equipment to be easily portable.

Table 2. Features of manual and electric centrifuges for 96-well PCR plates.

\begin{tabular}{ccc}
\hline & Manual Centrifuge (Salad Spinner) & Electric Centrifuge (Labnet MPS1000) \\
\hline Time of Centrifugation & $3 \mathrm{~s}$ & $20 \mathrm{~s}$ \\
Sample Capacity & Two 96 -well PCR plates & Two 96-well PCR plates \\
Maximum Speed & $760 \mathrm{rpm}(25 \times g)$ & $2500 \mathrm{rpm}(500 \times g)$ \\
Price & USD 18 & USD 710 \\
Power Supply & None & $\sim 120 \mathrm{~V}, 50 / 60 \mathrm{~Hz}$ \\
Weight & $0.59 \mathrm{~kg}$ & $1.5 \mathrm{~kg}$ \\
Installation Area & $205 \times 200 \mathrm{~mm}($ mobile $)$ & $190 \times 210 \mathrm{~mm}$ (immobile) \\
\hline
\end{tabular}

The manual centrifuge was associated with quick acceleration and deceleration and sufficiently spun the solutions in the two 96-well PCR plates after 3 s. Operation of the manual centrifuge did not require electricity, and the instrument functioned on a simple mechanism, and its operation was effortless. Moreover, the price of the salad spinner for the body of the manual centrifuge was notably less expensive than an electric centrifuge, costing only USD 18 (i.e., 1/40th of the cost of one electric centrifuge). Thus, the manual centrifuge developed in this study was simple, fast, inexpensive, and useful for spinning solutions down in 96-well PCR plates.

Funding: This work was supported by JSPS KAKENHI Grant Number 16K07409 (to K.M.), the MEXT-Supported Program for the Strategic Research Foundation at Private Universities Grant Number S1511023 (to K.M.), and the Institute for Fermentation (Osaka) Grant Number G-2019-2-067 (to K.M.).

Acknowledgments: The author wishes to thank A.K. (Kyoto Sangyo University) for allowing the use of an electric centrifuge (Labnet, MPS 1000 Mini Plate Spinner Centrifuge).

Conflicts of Interest: The author declares no conflict of interest.

\section{References}

1. Thomson, D.; Henry, R. Single-Step Protocol for Preparation of Plant Tissue for Analysis by PCR. Biotechniques 1995, 19, 394-397. [PubMed]

2. Strizhov, N.; Li, Y.; Rosso, M.G.; Viehoever, P.; Dekker, K.A.; Weisshaar, B. High-throughput generation of sequence indexes from T-DNA mutagenized arabidopsis thaliana lines. Biotechniques 2003, 35, 1164-1168. [CrossRef] [PubMed]

3. Xin, Z.; Velten, J.P.; Oliver, M.J.; Burke, J.J. High-throughput DNA extraction method suitable for PCR. Biotechniques 2003, 34, 820-824. [CrossRef] [PubMed]

4. Varshney, G.K.; Pei, W.; LaFave, M.C.; Idol, J.; Xu, L.; Gallardo, V.; Carrington, B.; Bishop, K.; Jones, M.; Li, M.; et al. High-throughput gene targeting and phenotyping in zebrafish using Crispr/Cas9. Genome Res. 2015, 25, 1030-1042. [CrossRef] [PubMed]

5. Gao, X.; Chen, J.; Dai, X.; Zhang, D.; Zhao, Y. An effective strategy for reliably isolating heritable and Cas9-free arabidopsis mutants generated by crispr/Cas9-mediated genome editing. Plant Physiol. 2016, 171, 1794-1800. [CrossRef] [PubMed]

6. Kweon, J.; Kim, Y. High-throughput genetic screens using crispr-Cas9 System. Arch. Pharm. Res. 2018, 41, 875-884. [CrossRef] [PubMed]

7. Wang, C.; Wang, K. Rapid screening of crispr/cas9-induced mutants using the ACT-PCR method. Methods Mol. Biol. 2019, 1917, 27-32. [PubMed] 
8. Woodman, M.E.; Savage, C.R.; Arnold, W.K.; Stevenson, B. Direct PCR of Intact Bacteria (Colony PCR). Curr. Protoc. Microbiol. 2016, 42, A3D1-A3D7. [CrossRef] [PubMed]

9. Okegawa, Y.; Koshino, M.; Okushima, T.; Motohashi, K. Application of preparative disk gel electrophoresis for antigen purification from inclusion bodies. Protein Expr. Purif. 2016, 118, 77-82. [CrossRef] [PubMed]

10. Azevedo, F.; Pereira, H.; Johansson, B. Colony PCR. Methods Mol. Biol. 2017, 1620, 129-139. [PubMed]

11. Jamal, M.A.; Sharma, S.P.; Chung, H.J.; Kim, H.J.; Hong, S.T.; Lee, S. Ultra-high efficient colony PCR for high throughput screening of bacterial genes. Indian J. Microbiol. 2017, 57, 365-369. [CrossRef] [PubMed]

12. Ahrberg, C.D.; Manz, A.; Chung, B.G. Polymerase chain reaction in microfluidic devices. Lab Chip 2016, 16, 3866-3884. [CrossRef] [PubMed]

13. Voytas, D. Agarose gel electrophoresis. Curr. Protoc. Mol. Biol. 2000, 51, 2-5. [CrossRef] [PubMed]

14. Lee, P.Y.; Costumbrado, J.; Hsu, C.Y.; Kim, Y.H. Agarose gel electrophoresis for the separation of DNA fragments. J. Vis. Exp. 2012, 20, e3923. [CrossRef] [PubMed]

15. Green, M.R.; Sambrook, J. Analysis of DNA by agarose gel electrophoresis. Cold Spring Harb. Protoc. 2019, 2019, pdb-top100388. [CrossRef] [PubMed]

16. Brown, J.; Theis, L.; Kerr, L.; Zakhidova, N.; O'Connor, K.; Uthman, M.; Oden, Z.M.; Richards-Kortum, R. A hand-powered, portable, low-cost centrifuge for diagnosing anemia in low-resource settings. Am. J. Trop. Med. Hyg. 2011, 85, 327-332. [CrossRef] [PubMed]

17. Marcos, R.; Santos, M.; Marrinhas, C.; Correia-Gomes, C.; Caniatti, M. Cytocentrifuge preparation in veterinary cytology: A quick, simple, and affordable manual method to concentrate low cellularity fluids. Vet. Clin. Pathol. 2016, 45, 725-731. [CrossRef] [PubMed]

18. Bhamla, M.S.; Benson, B.; Chai, C.; Katsikis, G.; Johri, A.; Prakash, M. Hand-powered ultralow-cost paper centrifuge. Nat. Biomed. Eng. 2017, 1, 1-7. [CrossRef]

19. Motohashi, K. Development of highly sensitive and low-cost DNA agarose gel electrophoresis detection systems, and evaluation of non-mutagenic and loading dye-type DNA-staining reagents. PLoS ONE 2019, 14, e0222209. [CrossRef] [PubMed]

20. Motohahi, K. Evaluation of the efficiency and utility of recombinant enzyme-free seamless DNA cloning methods. Biochem. Biophys. Rep. 2017, 9, 310-315.

(C) 2020 by the author. Licensee MDPI, Basel, Switzerland. This article is an open access article distributed under the terms and conditions of the Creative Commons Attribution (CC BY) license (http://creativecommons.org/licenses/by/4.0/). 